\title{
Europe, the Euro and German Demographic Renewal
}

\begin{abstract}
Access to the domestic market is nowadays the trump card of trade diplomacy. The larger the domestic market, the more effective it is. The euro is thus the decisive pillar of the European single market. The German debt brake is incompatible with the long-term stability of the euro. For as long as it applies, full employment can never be achieved in the eurozone as a whole. Under current fiscal policy, full employment would require unrealistically high export surpluses. A euro doomed to underemployment will collapse. Hence, the international fiscal order must also be applied among the nation states in the euro area. Germany's resulting obligations offer an opportunity for a German demographic renewal by aggressively encouraging the immigration of skilled workers.
\end{abstract}

\subsection{The Single Market}

When the process of European unification began after the Second World War with the European Coal and Steel Union and then the European Economic Community, the goal of these steps was to ensure peace in Europe. At the same time, economic recovery was closely linked to the East-West conflict and, in particular, the Cold War between the two world powers, the USA and the Soviet Union. For a long time, members of the common or "single" market were only countries that were also close allies of the USA by way of membership in NATO. It was only starting in the 1990s, after the fall of the Berlin Wall and the dissolution of the Soviet Union, that countries that were not part of NATO also joined the single market: in particular, Austria, Sweden and Finland. The political and military climate had changed. Apart from economic criteria, a "community of values" was now decisive for membership in the European Union-not participation in a military alliance 
anymore. But membership in a common market also requires that certain basic preconditions of a market-based economic order are fulfilled.

Among citizens, however, there is still no consensus today on which matters should be subject to a common and uniform approach in the EU. The Brexit vote in the summer of 2016 showed that certain EU regulations are so unpopular that a majority of voters may support their country withdrawing from the common market. Many people are of the opinion that the decisions taken in Brussels, Strasbourg and Luxembourg reflect a lack of understanding of the principle of subsidiarity.

If we compare the history of the process of European unification up to now and the formation and consolidation of the USA, we find that, in addition to the much greater linguistic diversity in Europe, there is also an important difference in the constitution of the two federal structures. In Europe, member states have the right to withdraw from the union. The individual states comprising the USA do not have such a right. Twice in the nineteenth century, under Jackson and later under Lincoln, the USA fought civil wars triggered by member states' wanting to secede. Twice, a federal army under the command of the president of the USA had to defeat a separatist army to avert secession. The right to withdraw from the European Union is, of course, closely connected to the fact that it would be unthinkable in the twenty-first century to prevent the secession of a member state by military means.

What are the conditions for the persistence of a union of states in which each member state has the right to secede? We want to examine this question from the point of view of economic policy in particular, using ideas that we have developed in the prior chapters of this book.

\subsection{Europe's Global Political Environment: International Demand Power}

Picking up on our analysis of free trade in the last chapter, we want here to point to the enormous dynamism of the global economy and of global society. It is not only the Chinese economic miracle that has marked world politics in recent decades. As Hans Rosling and his co-authors have convincingly demonstrated in their book Factfulness, many observers from rich countries have blinders on that prevent them from being sufficiently aware of the great progress that has been made in the developing countries and especially in the so-called emerging economies (cf. Rosling et al. 2018). We have already touched upon the rapidly increasing average life expectancy of the global population in Chap. 3 (on desired wealth). According to the 2017 UN population forecast, based on the trend in birth rates, the global population can be expected to peak in about 100 years and to decline again from then on (United Nations 2017). It is fairly certain that some of the countries that are still considered today as "emerging economies" — such as India, Brazil, Indonesia, Iran and others - will join the club of rich countries in the course of the twenty-first 
century. In the last $12-15$ years, for instance, per capita real income in India has doubled. At the same time, the Indian birth rate has fallen sharply.

We can thus assume that the relative importance of Europe in the global economy will decrease. The share of European GDP in global GDP will continue to fall. The rest of the world will become less and less dependent on European high-tech products. Whatever European technology can do, the technology of China, Japan, South Korea, Israel, Singapore, India or Brazil can increasingly do as well. The USA has long been Europe's equal in technical terms, even if there are differences from one sector to another, sometimes in favor of the USA, sometimes in favor of Europe.

No matter the form of government, public authorities are always interested in offering citizens as many employment opportunities as possible. Economic growth has thus to keep pace with population growth and increased labor productivity. As discussed in the last chapter, in light of the proximity of the Keynes world, the size of the domestic market is the most important card that any country can play in international trade diplomacy.

A world of potential international demand power is increasingly coming into being. The concept of demand-side market power comes from competition policy and antitrust law. It refers to the phenomenon of large retailers being able to obtain more favorable purchasing conditions in negotiations with manufacturers than smaller buyers are able to obtain. This has led, for example, to a strong process of concentration in the retail food sector. (Cf. various opinions of Germany's Monopoly Commission on the food retail trade, as well as Chap. V of its 2012 main report [Monopolkommission 2012].) If free trade cannot be relied upon as the institutional regime of the global economy, then it is also advisable for a continent like Europe to adapt to the phenomenon of international demand power.

Concretely, this means that - other things being equal-larger states or larger currency areas can expect to enjoy better conditions in international trade than smaller states or smaller currency areas. Of course, certain smaller countries-like, for instance, Switzerland or Israel or Singapore - can achieve or obtain advantages through superior flexibility, which may compensate for their lack of size. But here it is always a matter of specific, historically evolved advantages that are not available to every small state.

Today, better conditions of international trade mean, in particular, better export opportunities to other countries or currency areas.

We have already mentioned a striking example of international market power in the previous chapter: the effective threat by the US administration to prohibit German firms from exporting to the USA, if they violate US sanctions against Iran. Germany's exports to Iran are "peanuts" in comparison to German exports to the USA and already existing German direct investment in the USA. 


\subsection{The Euro and the Single Market}

In the debate that preceded the introduction of the euro, the proponents of a common currency saw it as a vehicle for accelerating the process of integration. The opponents argued that the member states were not yet ready for a common currency, given entirely different national "economic styles" (Müller-Armack; cf. Dietzfelbinger 1998). The time since its introduction has not led to a clear victory of the one side or the other. Friedman's (1997) prophecy that the euro would fail has not come true, but neither has it brought about the progress in European integration for which its proponents had hoped. The global economy has, however, adjusted to the fact that the euro will remain the currency of a large economic area.

The soaring value of the euro against the dollar before the 2007-2008 financial crisis is a thing of the past. The Greek crisis and the fragility of the southern euro countries forced the European Central Bank to adopt a policy of maintaining the lowest possible interest rates. Simultaneously, confidence in the stability of the eurozone waned on the international capital markets. As a result, the exchange rate of the euro against the dollar was significantly lower than it had been. This did not only help the competitiveness of the southern euro countries, but also the competitiveness of the considerably stronger northern euro countries. It is in no small measure thanks to this "weak" euro that Germany, before COVID-19, enjoyed its high export surpluses and thus too full employment and "healthy" public finances.

It should not be forgotten, however, that the resolutely expansionary fiscal policy pursued by the USA under President Obama made a major contribution to the overcoming of the 2007-2009 global financial crisis. Helped also by an expansionary monetary policy on the part of the Federal Reserve, the USA again became the engine of the global economy, which stabilized global demand for goods and services by running a substantial current account deficit.

The following analysis of the euro and its problems builds on previous analyses by various economists. Three books, in particular, should be mentioned here: Brunnermeier et al. (2016), Sinn (2014) and Stiglitz (2016).

Today, the euro area has an export surplus, which is important for the fact that the employment situation has improved and that, with the exception of Greece, no deflationary crisis has arisen in the southern euro countries. But the employment situation remains unsatisfactory in the southern euro countries. Many observers in Germany and other northern euro countries put the blame for this still unsatisfactory situation on the domestic policies of the southern countries, which, in their view, have not had the courage to undertake deregulatory measures. Both critics and supporters of current eurozone economic policy agree that the relative prices between the different eurozone countries are distorted. There is disagreement on whether correcting them should occur by way of further deflation in southern Europe or higher inflation in the northern part of the euro area. We do not want, however, to provide extensive analysis of this topical issue here. 
There is also the idea of splitting the eurozone into a northern eurozone with a strong euro- 1 and a southern eurozone with a weak euro-2. From the point of view of the southern countries, there is something to be said for this. For today's relatively "weak" euro is still stronger than a euro- 2 only comprising the southern countries would be. The current euro may be gratifyingly weak for German industry; nevertheless, it is precisely because of German industry that it is stronger than the southern euro countries could possibly want it at the moment.

The arguments of some commentators in favor of a strong northern euro or euro- 1 are not very convincing. This euro- 1 would have a significantly higher exchange rate against the dollar than the present euro. It would thus exert deflationary pressure on the northern euro countries, leading to an economic slowdown. With given fiscal policy, the latter would probably have to resort to intervening on the foreign exchange market, like Switzerland does, in order to prevent the euro-1 from having too high a dollar value. This is possible for the Swiss National Bank: Even a Trump administration had little against a deliberate weakening of the Swiss franc, since this is primarily achieved by the Swiss National Bank purchasing euros and thus strengthening the euro. But the weakening of the euro-1 by its central bank would have to be achieved by massively buying up dollars. This would, in turn, bring into action any US administration, which would attack such behavior as a violation of the rules of the system of free trade. In the interest of preserving free trade and also for the benefit precisely of the people in the euro-1 area, a northern euro or euro-1 would have to refrain from massive manipulations of the exchange rate against the dollar. In order not to be pushed into a recession or even depression and a deflationary trap by a high euro-1 exchange rate, the member states might have to make extensive use of fiscal policy to boost demand. At the same time, the monetary policy of the euro- 1 central bank would have to be aimed at maintaining the lowest possible interest rates. Debt brakes on the German model would thus be incompatible with membership in the northern euro area.

These observations on a hypothetical northern euro are based, of course, on our analysis that the OECD plus China region is in a Keynes world, or at least in the transitional zone between a Keynes world and a Friedman world, and can be expected to remain so for a long time. The details can be found in the previous chapter (Chap. 10) on the struggle between free trade and protectionism.

A "strong" northern euro is thus not even advisable for the potential members of the northern euro area themselves. Nonetheless, the thought experiment involved in imagining this sort of northern euro is of interest, because it makes clear the other side of this coin: namely, that the potential northern euro countries benefit from the fact that the euro is so weak due to the membership of the economically weaker southern euro states. As long as international economic policy tolerates this state of affairs, Germany can afford its debt brake, precisely because it uses the same currency as countries that are far removed from any debt brake.

In Germany, the current situation is often depicted as follows: Germany, with its high export surpluses, is the economic engine of the eurozone, inasmuch as these export surpluses and the resulting high employment in Germany also lead to higher 
German demand for goods from France, Italy, Spain, Portugal and Greece. This observation is correct to the extent that it holds other things being equal, i.e., at a given exchange rate of the euro against the dollar as reference currency and against other currencies. But it is misleading to the extent that Germany is in such a good position on the global market precisely because it is part of a monetary union with the countries whose economic engine it allegedly represents. For then it becomes clear that France, Italy, etc., suffer precisely from the fact that the euro area also includes Germany and the other more competitive member states. The euro is "too strong" for France, Italy, etc. and forces these countries into deflation. Once we see this connection between the euro exchange rate and German current account surpluses, nothing is left of the idea that Germany is the economic engine of the eurozone.

\subsection{The Euro as Pillar of the Single Market}

If our analysis in the previous chapter is correct, viz. to the effect that it is strategically advantageous for a region to be part of a large internal market, then Europe's single market represents an advantage for the people of Europe that goes beyond the advantages that are usually mentioned in international trade theory. What is at issue then is that an individual European nation like Italy, for example, not become the target of trade policy manipulations on the part of other big "markets" like the USA, China and India. The single market means precisely that trade policy issues are decided upon by its members collectively, thus preventing an imbalance in the strength of the negotiating positions of one of the global giants and any individual European country. The coordination of trade policy within Europe is thus important for ensuring that the community of values of the European nations can be sustained.

The problems arising for Great Britain after Brexit are also connected to the fact that it is far more interesting for any of the world's countries to have access to the European single market than to the British market. The European Union can certainly adopt a friendly "good neighbor" policy toward Great Britain-and thus reduce the separation pains that the latter will experience. And we have to hope that the remaining $27 \mathrm{EU}$ members are wise enough to adopt such a policy toward the renegade ex-member. It is by no means certain that they will, however-especially since not all 27 member states are in as good a position economically as Germany, for example. But, in any case, the backing that Great Britain enjoys in negotiations with non-European powers has been diminished by Brexit.

The current problems with Italy show that further withdrawals from the single market cannot be ruled out, even if such secession is not beneficial for the country in question. The stabilization of the single market is not automatic. It also cannot be ruled out that member states will formally remain in the European Union, but, nonetheless, adopt national measures that undermine the internal market rules. The problems that the European Union is currently having in terms of the rule of law 
with member states like Poland, Hungary or Romania demonstrate the extent of the potential centrifugal forces that the European Union has to resist.

A stable euro is an important, perhaps indeed decisive, pillar for holding the European Union together. Stable in two senses: firstly, as regards its purchasing power. In Chap. 9 on monetary stability and the stability of the open society, we discussed the relationship between a stable value of the currency and the stability of a free, democratic social order. But the stability of the euro also entails that citizens can rely on its continued existence.

If the euro were to fail and national currencies were to take its place again, this would be a sign of weakness for the European single market. Whatever the reason for the collapse of the common currency, in the new era of international economic policy, it will be seen by big non-European countries (the USA, China, India, Russia and Brazil, for example) as a signal that the European countries can be played off against each other: That the big countries can now bring the demand power created by their size to bear against the much smaller European countries, because the common defense of interests no longer seems to work in Europe. This can give rise to a diplomatic and political dynamic that then actually does lead to the de facto collapse of the rules of a common market.

Thus, for example, each of the individual national currencies could be linked to different potential candidates for the role of the future global reference currency. China's global "New Silk Road" strategy could thus be supplemented by a currency component. If, for example, the neo-D-mark is pegged to the yuan to counter the US accusation of currency manipulation for the purpose of devaluation, whereas the more inflation-prone national currencies like the neo-lira are pegged to the dollar, then, as a matter of course, Europe's national markets will also begin to grow apart.

Among other things, a common currency like the euro also serves to ensure that in the Keynes world, the lack of a Nash equilibrium for intra-European free trade cannot lead to new national protectionist strategies using exchange rate policy. For there is no national exchange rate policy to be abused anymore. The common currency thus directs the focus of national policy toward the rules that have to be followed if a country wants to remain part of the monetary union. One cannot draw the bow of discipling national policy via the common currency too tautly, however - otherwise it breaks. We will turn now to this last point in greater detail.

\subsection{The Problem of National Current Account Balances}

Germany exhibits a high export surplus and hence also a high current account surplus. And this is not only sporadically the case, but is practically a "structural" feature. To this export surplus, there also corresponds a substantial excess of aggregate savings as compared to aggregate investment. Ante COVID-19, households, the corporate sector and the state were are all running surpluses in Germany. This is unusual for the OECD countries. In most of them, both the corporate sector and the state run structural deficits. 
If each member state of the European Union had its own national currency, we would be able directly to apply the considerations that we presented in the chapter on free trade in the new era of international economic policy. The essence of our proposal was that in a Keynes world with low real interest rates, countries with current account surpluses should eliminate them by increasing their fiscal deficit. Germany would accordingly have to abandon its debt brake to fulfill its obligations under the balanced account agreement that we have proposed. In perfectly symmetrical fashion, in a Friedman world, countries with current account deficits would be obligated to reduce their fiscal deficit to contribute to lowering real interest rates. At present, however, we are clearly in the Keynes world of low real interest rates.

But this balanced account agreement remains attractive even if a group of countries has a common currency. This is the case for the euro. Thus, the balanced account agreement between the different currency areas should also apply for the euro area. Trump had accused Germany of engaging in a form of covert currency manipulation at the expense of American jobs by virtue of its membership in a monetary union with far weaker partners. If, in the Keynes world of the new era of international economic policy, the national priority is the creation or preservation of as many jobs as possible and no longer facilitating the most inexpensive possible imports, then the accusation is not entirely off-base. We do not share this view as far as German intentions are concerned. But the result is the same as it would be if Germany had deliberately joined a monetary union with weaker partners, in order to benefit from a weak currency for the purpose of creating jobs.

The anger of the other eurozone countries that Germany incurs as a result of its current account surpluses is a serious problem for the cohesion of the European Union and the political stability of the euro. We already showed above that the notion that Germany is the economic engine of the eurozone thanks to its immense export surpluses is misleading. The resultant strengthening of the euro against other world currencies, and, in particular, against the dollar, makes it more difficult for the weaker euro countries to achieve full employment. It is already the case today, when there is insufficient employment in the southern euro countries, that the euro area runs current account surpluses. With given fiscal policy and with full employment in the euro area as a whole, the current account surplus of the euro countries as a percentage of gross domestic product would be comparable to the surplus that Germany runs now. But, if dollar interest rates are no longer rising significantly, the exchange rate of the euro would then be far higher than it is today. But this means that such eurozone current account surpluses cannot occur.

In other words, if Germany and the other comparable northern euro countries retain their present fiscal policies, then the southern euro countries cannot reach the goal of high employment. If they tried to do so by way of additional public debt, the capital market would punish them with high risk premiums. It would not even be necessary for the European Commission to take any disciplinary action.

This would be a potentially explosive situation for the euro. At best, an extremely expansionary US fiscal policy with consequent high dollar interest rates could bring about a transition onto the terrain of the Friedman world. In political-economic terms, it is, however, likelier that under any USA presidency 
non-market interventions will take place in the USA of a sort that will take the world even further away from the virtues of free markets and free trade. As an example, we need only think of the price controls that were decreed by President Nixon at the height of the Vietnam crisis.

If there is no such extremely expansionary US fiscal policy, the impossibility of achieving full employment in the euro area with current northern European fiscal policy may deprive the euro of its integrative function. A revolt of the southern euro countries, such as has already been foreshadowed in various elections and protest movements, will then indeed lead to a partition of the euro zone, if not to an outright return to national currencies.

\subsection{Investment Promotion as the Solution?}

One often hears that governments should do more to encourage investment. The hope is that a higher rate of investment will lead to higher growth and a more dynamic economy. And it is also hoped that the gap between private saving and private investment will be reduced. Overregulation is frequently identified as an important obstacle to investment.

It is not our intention to examine the issue of investment conditions in detail in this book. We believe that our analysis of the private savings surplus is valid, regardless of whether the thesis that governments can and should create more favorable investment conditions is right or wrong. In dealing with the subject of excess saving, it is important to think not only in flow variables like "saving" and "investment," but also in stock variables like "desired wealth" and "real capital stock." Time variables are also helpful. Look at the ratio between "desired wealth" and "consumption per year" (the variable $Z$ from Chaps. 2 and 3 on the natural rate of interest and on desired wealth). Then compare it with the ratio between "real capital" and "consumption per year" (the variable $T$, i.e., the period of production, from Chaps. 2 and 4 on the natural rate of interest and on real capital).

There is no doubt that a government policy that promotes current investment can lead to an increase in the share of gross investment in gross domestic product. If, however, we ask whether such measures also increase the capital tied up in the production process relative to current consumption, we cannot avoid considering the specific nature of the investment promotion. The latter should, after all, be economically productive: We do not want, to use the Keynes example, to promote the construction of economically unproductive "pyramids," but rather the construction of such plant and equipment as increases productive capacities. Ultimately, investment promotion is supposed to help to raise peoples' standard of living. This observation is practically identical to the following one: Ultimately, promotion of private investment is supposed to improve consumption possibilities. But this alone does not tell us whether public promotion of investment increases or decreases the ratio between the capital tied up in the private system of production and total consumption. 
A more precise analysis reveals the following: At a real interest rate $r$ that is a correct intertemporal price signal, investment promotion that does nothing other than increase the capital intensity of the production process with the same technology only makes sense if this interest rate is greater than the steady state growth rate $g$. This is the Golden Rule of Accumulation, which we derived in generalized form in Chap. 2. If we are in the Keynes world, however, then $r<g$ holds (cf. also Blanchard 2019). Hence, for the Keynes world, public promotion of a pure increase in capital intensity with the same technology is out of the question, because it leads to sustained lower consumption.

Investment promotion whose purpose is to change technology is a particular form of promoting economic growth. Whether-other things being equal-this form of promoting technical progress is likely to increase the capital tied up in the private production process has to be studied more closely. If we think of the buzzword of digitalization, which is so popular nowadays, skepticism is in order. When Germany's governing coalition launches a program for promoting artificial intelligence, it has, above all, the competitiveness of German industry in the global economy in mind. The point is to create jobs in Germany and to protect existing jobs by giving employees additional training. But whether this German promotion of growth increases or decreases the capital tied up in the global production process cannot be determined a priori from the fact that it ensures that there are more jobs in Germany. It could be that jobs are thus created in Germany, but using machines that eliminate existing jobs in the global economy or at least reduce the average roundaboutness of production in the global economy.

In the theoretical literature, there is a simple model that gives an answer to the question posed here on the amount of capital tied up in production (Solow et al. 1966). In this model, technical progress is "embodied." Each individual technical advance is only introduced into the production process by building equipment (machines) that translates this advance into practice. When, for example, a particular step in the production process gets automated, the old equipment is scrapped and replaced by new equipment.

In this model, we can now ask how the ratio of the capital tied up in production to current consumption changes, if, at a given steady-state real interest rate, the rate of technical progress is increased. Solow et al. (1966) model is analyzed in Weizsäcker (2021, Chap. 5, Sect. 1), where there is a clear answer to this question: At a given real interest rate, the relative amount of capital tied up in the production process (i.e., this capital divided by current consumption) is less, the greater the rate of technical progress.

To the extent that this outcome of the model is representative for the real world, we arrive at the following conclusion: In a Keynes world-namely, in a world with low real interest rates - an economically sensible form of investment promotion does nothing to increase the ratio between capital tied up in production and current consumption. The opposite is rather the case.

The intuition corresponding to this outcome is as follows: The greater the rate of technical progress, the faster the real capital stock "turns over" or, in other words, the faster it is renewed. A greater rate of technical progress leads to the share of 
gross investment in gross domestic product also being greater. But the machines lose value faster. Their useful life is shorter, if technical progress is greater. But a shorter lifespan of plant and equipment leads to less capital being tied up in relation to the output produced annually by this capital together with the other factors of production, labor and land. Every economist knows that the capital tied up in the provision of housing as compared to annual value output is much greater than the capital tied up in the production of industrial goods. And every informed observer of economic life is aware that the lifespan of residential buildings is far longer than the economically useful life of production facilities in manufacturing. The economically useful life of fixed assets is the most important variable for determining the relative amount of capital tied up in production processes. Faster technical progress reduces the economically useful life of plant and equipment.

As already noted at the outset of our book, we can sum up our main thesis in the following sentence: The lifespan of people is rising, the lifespan of machines is falling.

Public promotion of private investment may or may not make sense for other reasons, depending on the specific situation. But it contributes nothing to solving the problem of excess private savings.

Of course, a deviation from the steady state can generate a temporary fireworks display of publicly induced increased private investment and thus boost the economy. Inasmuch as the problem is not the structural excess of private savings, but a temporary deficiency in the "animal spirits" of potential investors, a classical Keynesian strategy of encouraging investment through tax breaks or public subsidies may well be helpful. In this sort of situation, these stimulus measures also increase the value of existing plant and equipment, which are thus more fully utilized. The side effect of investment promotion on the value to existing plant and equipment is in this case the opposite of the effect when growth is promoted by encouraging technical progress.

\subsection{A European Balanced Account Agreement, but "No Bailouts"}

German authorities made the bitter pill of separation from the D-mark sweeter for German voters by promising them a euro that is subject to monetary rules under which German taxpayers would never have to pay for the public debt of other member states no matter what. This promise was not kept: Greece was supposedly "too big to fail."

But the Greek crisis also fits the general empirical finding that the insolvency of a state is always accompanied by a current account deficit of the country in question. No one fears Japanese fiscal insolvency, even though, relative to domestic product, Japan's debt is greater than that of Greece was at the start of its crisis.

This finding can be used to argue for the following arrangement for the eurozone countries: 
The balanced account agreement that we proposed in the last chapter should not only be applied to the current account of the euro area as a whole, but also to the current accounts of the individual members of the eurozone. In addition, however, the no-bailout principle should be reaffirmed: Every member state is responsible for its own solvency. No country may expect other eurozone countries to relieve it of the burden of its public debt.

A balanced account agreement on the level of the individual euro area countries is necessary, if only because otherwise the euro area as a whole will not be able to fulfill its obligations under the worldwide balanced account agreement. This especially applies for the part of the balanced account agreement relating to the Keynes world, in which interest rates on the global capital market are low. Due to European demographics, the euro area tends to have a particularly high private savings surplus. If the eurozone or the European Union assumes the obligation to maintain a balanced current account, then, in light of decentralized responsibility for fiscal policy, it can only meet this obligation if the member states, in turn, assume analogous obligations. This means that if we are in a Keynes world, the countries with current account surpluses must quickly increase their fiscal deficits. This is all the more urgent inasmuch as the weaker eurozone members are on their own as far as the security of their public debt is concerned. They have, therefore, to pursue a very cautious fiscal policy; and hence, they cannot make any contribution to reducing the current account surplus of the euro area by undertaking a more expansionary fiscal policy.

The instruments to be used in implementing this sort of intra-European balanced account agreement will not be discussed in detail here. But we will touch upon a few points regarding the German case in the next section.

\subsection{The Result for Germany: Demographic Renewal}

The upshot of our analysis is this: We can expect to be in a Keynes world for a long time, since the tendency of the natural rate of interest is to become increasingly negative. Hence, there must also be an intra-European balanced account agreement. The fiscal policies of the eurozone member states have to be put at the service of such a balanced account agreement. Within the eurozone, complete national autonomy in fiscal policy is no longer compatible with the integrative function of the euro in maintaining a truly functional common market in Europe. And in the new era of international economic policy, Europe needs the latter. Political economy thus teaches us that the German debt brake is incompatible with upholding the commercial interests of the European and hence also the German population. 
A German fiscal strategy compatible with the proposed balanced account agreement could consist of increasing public investment far beyond the level presently envisaged in medium-term fiscal planning. Publicly financed infrastructure is normally complementary to private real capital. Better transport routes, a better supply of well-educated, highly skilled workers, and better publicly funded research institutions all increase the profitability of private real capital.

Hence, at low interest rates and with a current account surplus, an increase in public deficits does not crowd out private investment, so long as this increase serves to finance public investment.

Such a program of deficit-financed increased public investment also serves to promote the immigration of skilled workers from abroad and especially the faster integration of refugees into the labor market and into German society. It thus also represents a contribution to improving the age distribution of the population living in Germany.

As concerns this last point, let us recall what a contrast there is between the UN world population forecasts and the Federal Statistical Office's projections of how Germany's population will evolve. Figures 11.1 and 11.2 show this contrast.

Since the completion of the 13th Coordinated Population Projection in 2015, there has been a major influx of refugees into Germany. Hence, in 2017, the Federal Statistical Office supplemented variant 2 of the population forecast by a variant $2 \mathrm{~A}$. Variant 2A temporarily increases net immigration relative to variant 2 and then, like in variant 2 , anticipates net immigration of 200,000 persons per year starting in

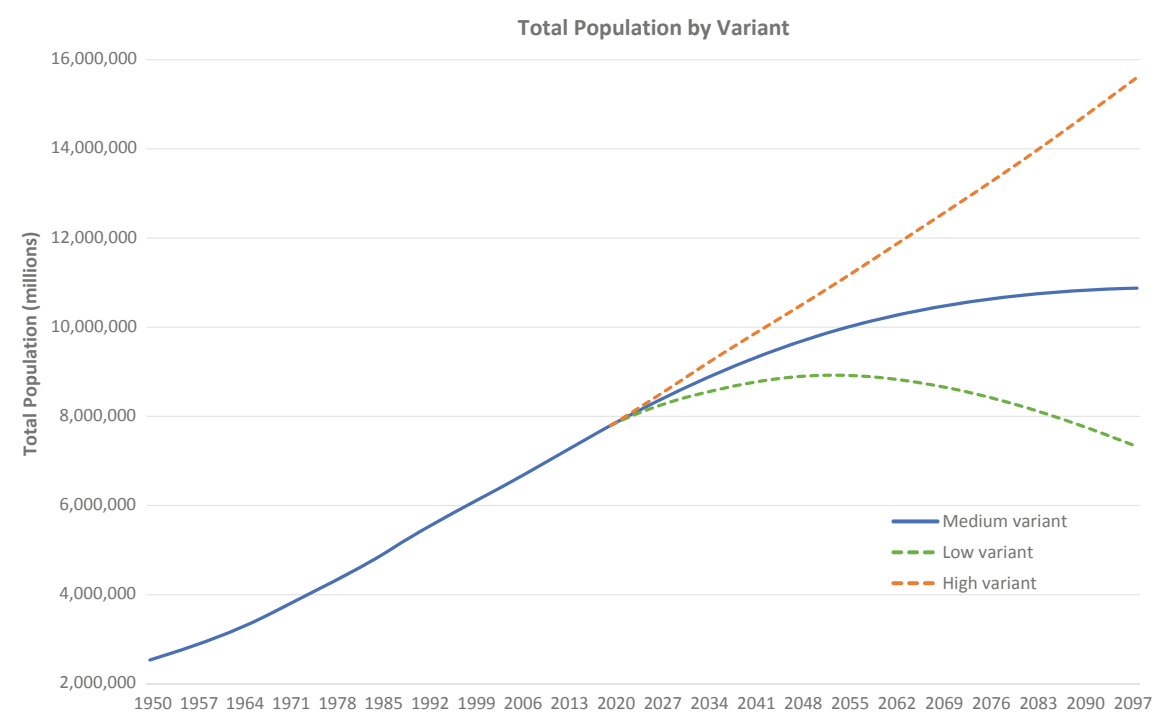

Fig. 11.1 UN world population prospects. Source United Nations (2017) 


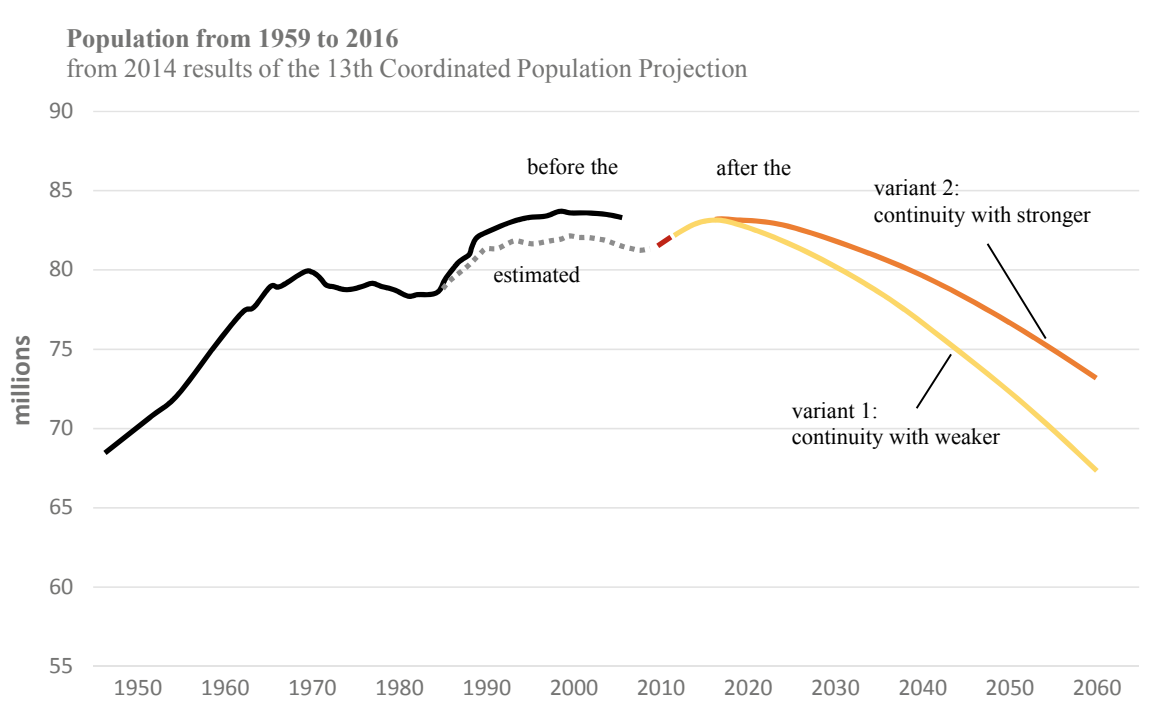

Fig. 11.2 Population development in Germany, 1950-2060. Source Authors' presentation based on data from Federal Statistical Office Germany (Statistisches Bundesamt 2015)

2021. Moreover, the birth rate has been raised from 1.4 to 1.5 children per woman. This results in a population of 76.5 million people in 2060 .

Based on the Federal Statistical Office's Coordinated Population Projection, we can see by comparing variant 1 (net immigration of 100,000 people per year) and variant 2 (net immigration of 200,000 people per year) that a difference of 100,000 people per year in net immigration leads to a difference of around five million people in the population in 2060 . Hence, assuming variant $2 \mathrm{~A}$, we can calculate that net immigration of approximately 350,000 people per year would be sufficient to stabilize Germany's population in the long term.

We advocate using the outlined setup of a global balanced account agreement, in order to manage Germany's obligations under the agreement so that they give rise to German demographic renewal. Here, some further remarks on this.

It is absurd that in a world where there is still high population growth, the population of one of the best governed countries in the world, viz. Germany, should fall. We believe that this absurdity will not become reality. Either Germany will continue to prosper: In this case, the pressure of immigration and the pull for immigration (the latter because of the great need for skilled workers) will be so strong that the population in Germany will not decline. Or: Germany will do so poorly that young skilled workers will emigrate, thus making it no longer possible to finance the welfare state, thus accelerating the loss of population, and thus making conditions even worse- so that, in the end, it is no longer possible to say that Germany is one of the best governed countries in the world. 
Hence, demographic renewal should be strived for in any case. If public investment is tailored to this goal, the resulting boost in domestic demand would lead anyway to a fall in Germany's current account surpluses. German demographic renewal would thus represent an important contribution to realizing a global balanced account agreement.

\subsection{A "Just" Distribution of Employment Opportunities}

A program for German demographic renewal like the one that we have proposed here can also be understood as the better way of developing German prosperity. Thanks to the elimination of current account surpluses that goes with it, it also helps the other eurozone countries. It thus serves to stabilize the euro and the European single market. In the context of the new era of international economic policy, these favorable effects of such a policy for other countries are also good for Germany. It is thus not a policy that is implemented at the expense of some other group, whether domestically or abroad. The benefit that other countries derive from the German policy shift does not conflict with the benefit that Germany itself derives from the policy. It is a "win-win" situation.

But, in addition, it is worth pointing out that the return on Germany's net exports of savings leaves much to be desired. By far the greater part of German capital exports are invested in loans with "fixed" interest rates. We put the modifier in quotation marks, because such investments have already proven to be the source of major losses on several occasions. We need only think of the German regional banks [Landesbanken] that failed due to misguided investments abroad, thus costing taxpayers a great deal of money. The returns achieved on nominally fixed-rate foreign investments are minimal in today's Keynes world. On our assessment, the overall economic benefit of the public investment proposed here is far greater. If this investment is viewed as part of the process of demographic renewal that we have called for, then the gain in prosperity can be seen not only in a given population enjoying better public infrastructure, but also in the fact that the influx of industrious immigrants that it triggers serves to improve the age distribution of the population, reducing the relative share of retirees. People already living in Germany today and their descendants benefit from the arrival of the newcomers thanks to the better age structure.

Instead of the "décadence" of a shrinking population on German soil, Germany will become a country of new beginnings: a magnet for young, industrious people from all over the world. The USA, the traditional global magnet for immigration with its entrepreneurial dynamism, can serve as model, if it is combined with the specifically European irenicism of the German welfare state: a welfare state that is big enough to fulfill its specific functions, but not so sprawling as to interfere with economic incentives - a welfare state that provides support, but also makes demands. 
Moreover, we should not forget the implicit public debt that arises under current fiscal policy due to the "wobbliness" of the euro. The Damocles sword of a possible Italian insolvency and withdrawal of Italy from the euro has to be kept in mind. If such a scenario appears imminent, there is a danger that Germany, at the head of the strong euro states, would provide financial assistance to avert Italy's insolvency, keep it in the euro, and thus avoid greater damage. The implicit "quasi-guarantee" that Germany provides for Italian public debt is obviously not written down anywhere. But no private guarantor of such liabilities would undertake this sort of guarantee without requiring the borrower to pay a substantial fee every year. As Milton Friedman said, "There is no such thing as a free lunch." The advantages that German exporters derive from the weakness of the euro come with an implicit price: The capital market assumes that Germany is providing an implicit guarantee of the sort discussed, precisely because it is aware of the advantages of euro weakness for German prosperity. The turbulence that disappointing this expectation would provoke on the capital market would already be reason enough for German authorities to take the path of least resistance and "pay up."

In other words, the German guarantee of the euro with its current membership can only be implicit and not explicit, so that the capital market has to live with the risk that someday Germany might not "pay up" after all. For this is the only way that the euro remains in its currently weak state that offers German exporters this competitive advantage.

The implicit debt that we have discussed here can be massively reduced, if Germany submits to a balanced account agreement of the sort that we have described - and attaches a declaration to it to the effect that, after massively reducing its current account surplus, it no longer considers itself obliged to prop up financially another eurozone country that is starting to founder under its public debt burden.

The basic idea of the balanced account agreement can also be expressed as follows. Nation states still retain the monopoly on the use of violence. Hence, only nation states can bring about a negative net wealth of their respective public sectors, so that citizens can enjoy net wealth greater than their real assets. Due to the negative natural rate of interest, it makes sense for nation states to make ample use of this possibility deriving from their monopoly on the use of violence. At an interest rate level below the growth rate of the economy, the collective public debt ratio $D$ can be maintained without burdening the future. (Cf. also the AEA Presidential Lecture by Olivier Blanchard of 4 January 2019: Blanchard 2019.) If raising a national public debt ratio $D$ when interest rates are low does not harm one's own country, does not burden future generations, and in fact benefits other countries, then ideas of global justice will also change. It will then be regarded as just for countries that can afford higher public debt without affecting their credit rating to make use of this possibility, so that countries that have a problematic credit rating can improve it by reducing their public debt with the collective public debt ratio $D$ remaining constant. 
Germany should not pay off Italy's public debt, but it is in Germany's own interest to increase its own debt, because, among other reasons, it will then be easier for Italy itself to reduce its level of indebtedness.

\section{References}

Blanchard, Olivier. 2019. Public Debt and Low Interest Rates, AEA Presidential Lecture 2019. American Economic Review 109 (4): 1197-1229.

Brunnermeier, Markus K., Harold James and Jean Pierre Landau 2016. The Euro and the Battle of Ideas. Princeton (NJ): Princeton University Press.

Dietzfelbinger, Daniel. 1998. Soziale Marktwirtschaft als Wirtschaftsstil - Alfred Müller-Armacks Lebenswerk. Gütersloh: Kaiser.

Friedman, Milton. 1997. Why Europe Can't Afford the Euro. The Times. 19 November 1997.

Monopolkommission. 2012. Neunzehntes Hauptgutachten der Monopolkommission 2010/2011. Bundestagsdrucksache 17/10565. Bonn: Monopolkommission.

Rosling, Hans, Ola Rosling and Anna Rosling Rönnlund. 2018. Factfulness. New York (NY): Flatiron Books.

Sinn, Hans-Werner. 2014. The Euro Trap. Oxford: Oxford University Press.

Solow, Robert M., James Tobin, Carl Christian von Weizsäcker and Menahem Yaari. 1966. Neoclassical Growth with Fixed Factor Proportions. Review of Economic Studies XXXIII 2: 79-115.

Statistisches Bundesamt. 2015. 13. Koordinierte Bevölkerungsvorausberechnung. Wiesbaden: Statistisches Bundesamt.

Stiglitz, Joseph. 2016. The Euro: How a Common Currency Threatens the Future of Europe. New York (NY): Norton.

United Nations. 2017. United Nations, Department of Economic and Social Affairs, Population Division, World Population Prospects: The 2017 Revision, Key Findings and Advanced Tables. ESA/P/WP/248. New York (NY): United Nations.

Weizsäcker, Carl Christian von. 2021. Capital Theory of the Steady State - Or: T+L=Z-T. https://www. coll.mpg.de/Weizsaecker/CapitalTheory2021 and https://www.springer.com/9783658273620.

Open Access This chapter is licensed under the terms of the Creative Commons Attribution 4.0 International License (http://creativecommons.org/licenses/by/4.0/), which permits use, sharing, adaptation, distribution and reproduction in any medium or format, as long as you give appropriate credit to the original author(s) and the source, provide a link to the Creative Commons license and indicate if changes were made.

The images or other third party material in this chapter are included in the chapter's Creative Commons license, unless indicated otherwise in a credit line to the material. If material is not included in the chapter's Creative Commons license and your intended use is not permitted by statutory regulation or exceeds the permitted use, you will need to obtain permission directly from the copyright holder. 